\section{Rancang Bangun Sistem Informasi Pelatihan dan Penelitian pada Badan Kependudukan Keluarga Berencana Nasional (BKIBN) Kalimantan Selatan}

\section{Yuslena Sari}

Program Studi Teknologi Informasi, Universitas Lambung Mangkurat

\section{yuzlena@ulm.ac.id}

\section{Pendahuluan}

Badan Kependudukan dan Keluarga Berencana Nasional (dahulu Badan Koordinasi Keluarga Berencana Nasional), disingkat BKKBN Provinsi Kalimantan Selatan, adalah Lembaga Pemerintah Non Departemen Indonesia yang bertugas melaksanakan tugas pemerintahan di bidang keluarga berencana dan keluarga sejahtera (Presiden Republik Indonesia, 2010). BKKBN mempunyai 4 (empat) tujuan strategis yang ingin dicapai satu diantaranya adalah "Penguatan tata kelola, penelitian dan pengembangan bidang Keluarga Berencana" (Kedeputi Bidang Pelatihan, 2020). Berkaitan dengan tujuan strategis tersebut, Deputi Bidang Pelatihan, Penelitian dan Pengembangan (Latbang) adalah sebagai unsur pelaksana sebagian tugas dan fungsi BKKBN di bidang pelatihan, penelitian dan pengembangan yang berada di bawah dan bertanggung jawab kepada Kepala BKKBN (Kedeputi Bidang Pelatihan, 2020).

Sehubungan dengan tugas pelatihan dan penelitian yang dilaksanakan oleh Latbang BKKBN, banyak kendala ditemukan pada proses kegiatan pelatihan dan penelitian. Menurut keterangan dengan kepala Deputi Bidang Latbang BKKBN Provinsi Kalimantan Selatan, Uniek Mulyaning Sari bahwa Latbang BKKBN rutin melaksanakan pelatihan dan penelitian setiap tahunnya. Kendala yang dihadapi diantaranya adalah pengelolaan data pelatihan dan besarnya biaya operasional penelitian. Dengan kendala-kendala
Deputi Latbang Badan Kependudukan Keluarga Berencana Nasional (BKKBN) Kalimantan Selatan setiap tahunnya melaksanankan banyak pelatihan dan program penelitian dengan total biaya yang besar. Secara manual, administrasi kegiatan-kegiatan tersebut sangat sulit. Strategi mempermudah proses tersebut adalah dengan membuat sistem informasi berbentuk website. Perancangan sistem informasi pelatihan dan penelitian pada deputi Latbang BKKBN Kalimantan Selatan menggunakan metode perancangan berbasis Unified Modelling Language (UML) yaitu diagram usecase. Tujuannya untuk manajemen data dan menghemat biaya operasional. Proses testing sistem informasi pelatihan dan penelitian BKKBNN Kalimantan Selatan menggunakan black-box dan usability. Hasil dari Pengujian sistem menggunakan black-box berhasil $100 \%$ dan untuk hasil usability mendapat nilai 3,905 dari rentang nilai 1 (sangat sulit) - 5 (sangat mudah). Sistem informasi ini telah diimplementasikan dan dapat mengatasi kendala proses manajemen data, efisiensi waktu dan menghemat biaya operasional proses pelatihan dan penelitian pada Deputi Latbang BKKBN Kalimantan Selatan.

Kata kunci: BKKBN, sistem informasi, UML, black-box, usability

Diajukan: 31 Mei 2020

Direvisi: 2 Juni 2020

Diterima: 16 Juni 2020

Dipublikasikan online: 17 September 2020

tersebut, maka hal tersebut perlu mendapat perhatian yang serius. Sebuah sistem informasi berbentuk website diusulkan untuk memecahkan permasalahan tersebut.

Menurut Arvidsson, dkk. (2014), sistem informasi adalah strategi efektif untuk keberlangsungan hidup jangka panjang sebuah organisasi. Sementara itu banyak penelitian tentang sistem informasi yang telah menyelaraskan niat strategis organisasi dengan investasi dalam kemampuan teknologi informasi, mampu mengatasi tantang di organisasi dan menerapkan sistem informasi dengan sukses (Galliers, dkk, 2012; Kornberger \& Clegg, 2011; Merali, dkk, 2012; Thomas \& Johnson, 2012).

Atas dasar pertimbangan tersebut, maka dibuatlah Rancang Bangun Sistem Informasi Pelatihan dan Penelitian pada Badan Kependudukan Keluarga Berencana Nasional (BKKBN) Provinsi Kalimantan Selatan. Hasil dari penelitian ini adalah sebuah sistem informasi yang dapat memudahkan Latbang BKKBN dalam melaksanakan penelitian dan pelatihan.

\section{Metode}

Perancangan proses di sini, peneliti menguraikan permodelan proses sistem yang dibuat menggunakan permodelan fisik menggunakan UML (Unified Modelling Language). UML merupakan suatu permodelan secara visual untuk sarana perancangan sistem berorientasi objek(Dennis, dkk, 2012; Evans, dkk, 1998; Padmanabhan, 2012). Kemudian, UML sendiri menjadi

Cara mensitasi artikel ini:

Sari, Y (2020) Rancang Bangun Sistem Informasi Pelatihan dan Penelitian pada Badan Kependudukan Keluarga Berencana Nasional (BKKBN) Kalimantan Selatan. Buletin Profesi Insinyur 3(2) 063-069 
bahasa standarisasi untuk visualisasi, menetapkan, membangun dan mendokumentasikan artefak suatu sistem perangkat lunak. Jadi, UML ini berguna untuk memberikan gambaran bagaimana perangkat lunak dapat bekerja ketika menjalankan perintah-perintah. Pada penelitian ini peneliti menggunakan UML dengan membuat model usecase diagram dan activity diagram.

\section{Flowchart Sistem}

Sistem yang diusulkan terdiri dari dua modul yaitu modul pelatihan dan modul penelitian. Untuk modul pelatihan dimulai dari admin membuat akun pengguna untuk widyaiswara dan pimpinan. Kemudian admin membukakan pelatihan baru. Dilanjutkan dengan widyaiswara yang membuat soal pre-test. Kemudian peserta dapat mendaftar menjadi peserta pada pelatihan tersebut setelah melakukan registrasi akun peserta. Admin dapat menyetujui atau menolak pendaftaran ini. Setelah disetujui peserta diminta mengerjakan pre-test. Setelah itu widyaiswara dapat menambahkan materi pada pelatihan tersebut. Pesera yang telah menyelesaikan pre-test dapat mengunduh dokumen materi. Kemudian widyaiswara membuat soal untuk post-test. Setelah itu peserta dapat mengerjakan post-test. Setelah mengerjakan peserta diminta untuk mengisi evaluasi terhadap pengajar dan penyelengaraan pelatihan. Pimpinan dapat melihat hasil evaluasi dari pelatihan yang dilaksanakan. Flowchart untuk modul pelatihan dapat dilihat pada Gambar 1.

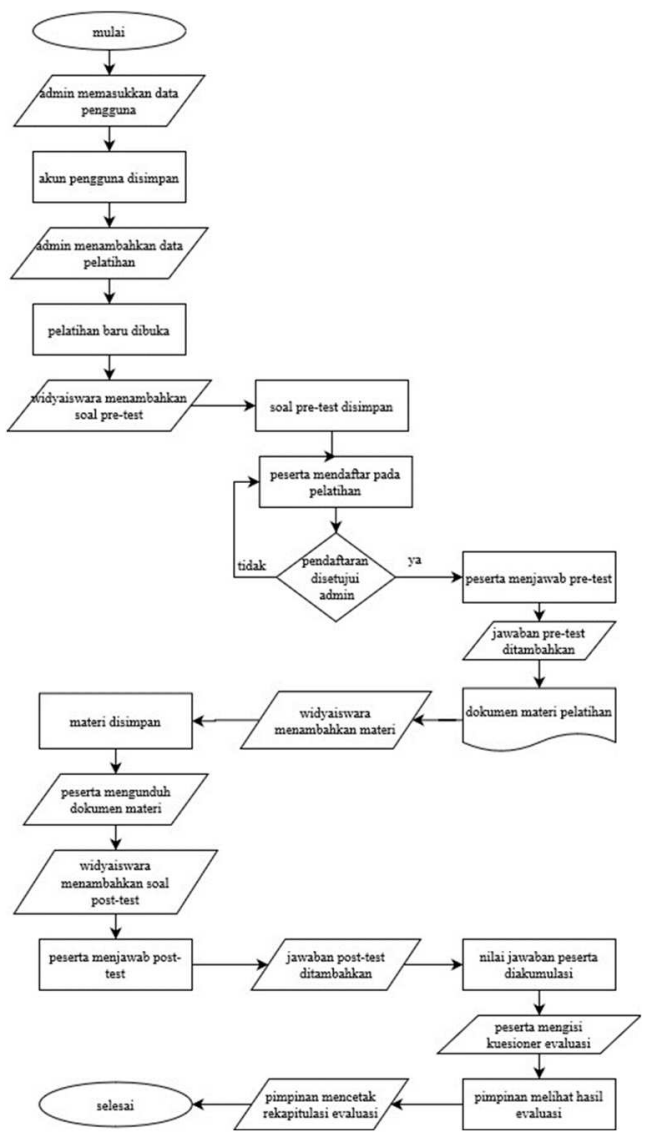

Gambar 1 Flowchart modul pelatihan

Sedangkan pada modul penelitian dimulai dengan admin membuatkan akun untuk peneliti, enumerator, dan pimpinan. Admin membuka penelitian baru. Kemudian admin mendaftarkan akun peneliti dan enumerator untuk penelitian tersebut. Selanjutnya peneliti menambahkan kuesioner untuk penelitian tersebut. Setelah selesai enumerator dapat mulai mengisi kuesioner. Peneliti dapat melihat semua tanggapan dari responden. Setelah selesai melakukan penelitian peneliti dapat mengunggah dokumen laporan hasil penelitian pada sistem sebagai pengarsipan. Pimpinan dapat mengunduh dokumen laporan tersebut. Flowchart untuk modul penelitian dapat dilihat pada Gambar 2.

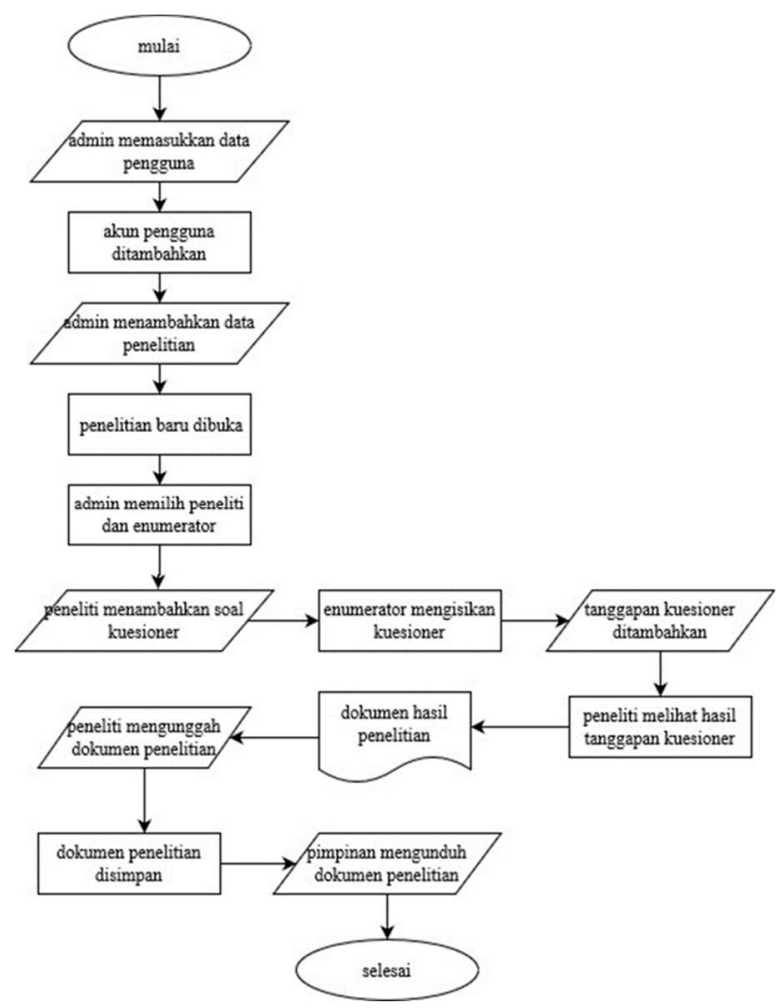

Gambar 2 Flowchart modul penelitian Desain Use Case Diagram

Usecase Diagram menggambaran interaksi yang dapat dilakukan antara aktor atau pengguna dengan sistem. Dengan Usecase Diagram dapat dilihat fungsi fungsi apa saja yang terdapat di dalam sistem dan siapa saja aktor yang dapat menggunakan fungsi - fungsi tersebut. Sistem yang dibuat kali ini terdiri dari dua modul yakni Pelatihan dan Penelitian.

1. Modul Pelatihan

Dalam modul pelatihan, terdiri dari empat aktor yakni: widyaiswara, peserta, pimpinan dan admin. Aktor sebagai widyaiswara merupakan pengendali dari jalannya sebuah pelatihan yang bertanggung jawab terhadap materi dan tes dalam suatu pelatihan. Peserta sebagai aktor yang akan menerima materi dan mengerjakan tes serta mengisi lembar kuesioner penilaian. Pimpinan merupakan pengguna yang dapat melihat hasil dari pelatihan secara keseluruhan. Dan admin merupakan aktor yang dapat membukakan pelatihan baru dan mengendalikan semua proses yang 
ada dalam pelatihan. Berikut usecase diagram untuk modul pelatihan.

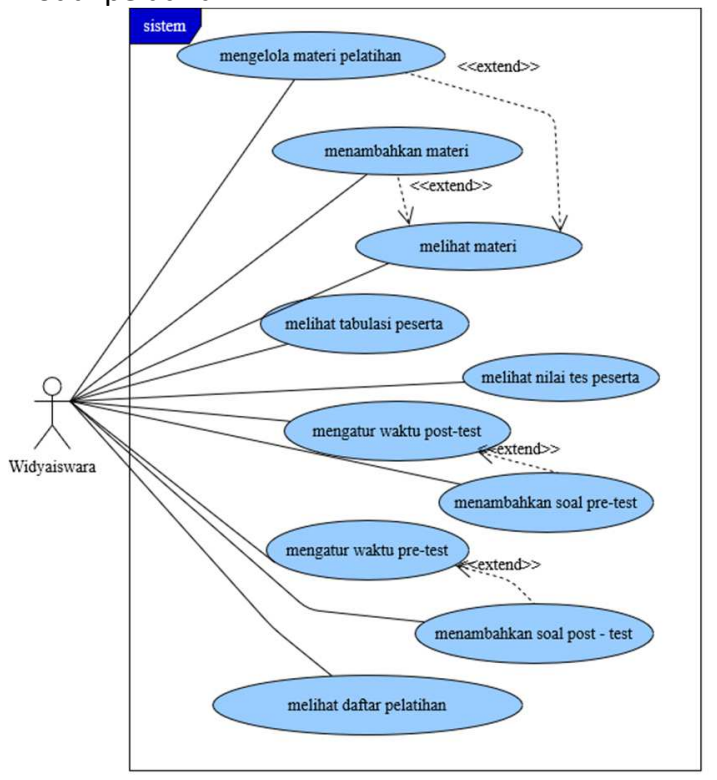

Gambar 3 Usecase Diagram Widyaiswara

Widyaiswara seperti pada Gambar 3 daoat mengelola hal yang berhubungan dengan materi pelatihan. Yaitu dapat menambahkan dan mengelola materi, melihat nilai peserta, melihat tabulasi peserta, dan menambahkan soal pre-test dan posttest.

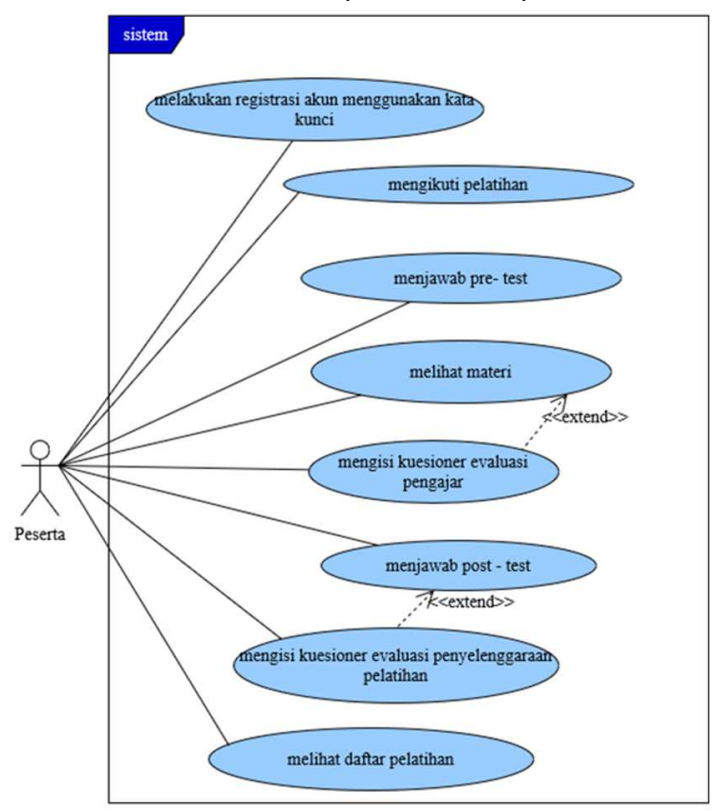

Gambar 4 Usecase Diagram Peserta

Peserta seperti pada Gambar 4 dapat melakukan registrasi akun, mengikuti pelatihan, menjawan pretest, melihat materi, mengisi kuesioner penilaian pengajar, menjawab soal post-test dan mengisi kuesioner penilaian penyelenggara pelatihan.

Admin memiliki akses penuh terhadap modul pelatihan seperti pada Gambar 5, admin dapat menambahkan dan mengelola pengguna baru secara langsung melalui akunnya, menambahkan dan mengelola data pelatihan, menyetujui pendaftaran peserta pelatihan, menambahkan peserta pelatihan dan mengelola kata kunci.

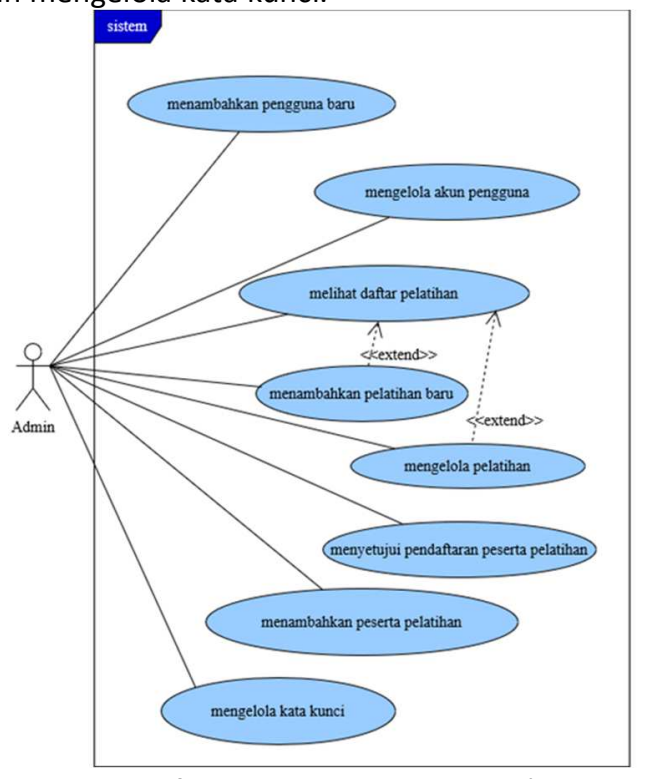

Gambar 5 Usecase Diagram Admin

Untuk pimpinan sesuai dengan Gambar 6 dapat melihat hasil penilaian penyelenggara pelatihan, melihat data pelatihan, melihat hasil penilaian pengajar pelatihan dan melihat tabulasi pelatihan.

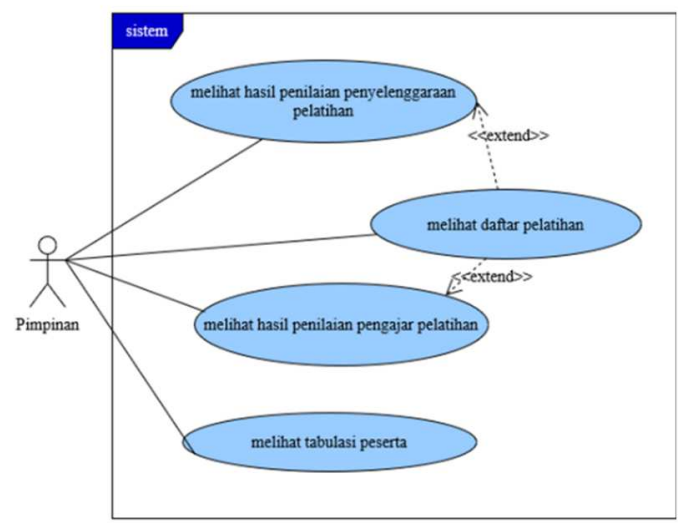

Gambar 6 Usecase Diagram Pimpinan

\section{Modul Penelitian}

Dalam modul pelatihan, terdiri dari empat aktor yakni: peneliti, enumerator, pimpinan dan admin. Aktor sebagai peneliti akan bertanggung jawab terhadap penelitian yang dilakukannya seperti pembuatan kuesioner untuk pengumpulan data serta pengunggahan laporan akhir penelitian. Enumerator sebagai aktor yang akan mengisikan tanggapan dari responden untuk kuesioner penelitian. Pimpinan sebagai aktor yang dapat melihat hasil dari penelitian. Dan admin sebagai aktor yang membukakan penelitian baru dan mengendalikan semua proses yang ada di dalam penelitian. Berikut usecase diagram untuk modul penelitian:

Seperti pada Gambar 7, Peneliti dapat mengelola penuh penelitian miliknya pada sistem tersebut. Diantaranya adalah peneliti dapat mengelola deskripsi penelitian, membuat dan mengelola pertanyaan 
kuesioner, melihat tanggapan kuesioner dan mengunggah dokumen hasil penelitian.

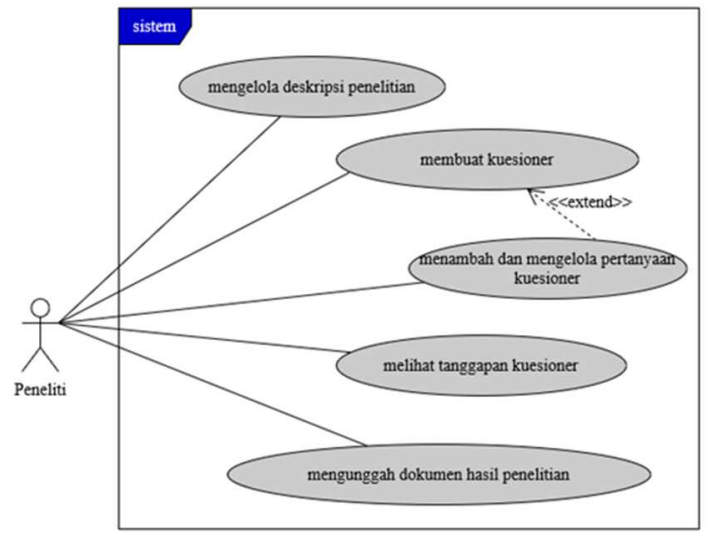

Gambar 7 Usecase Diagram Peneliti

User admin seperti pada Gambar 8 dapat mengelola modul penelitian dengan penuh. Yaitu admin dapat menambahkan dan mengelola akun secara langsung, menambahkan penelitian baru, menambahkan peneliti dan enumerator untuk suatu penelitian dan mengelola data penelitian.

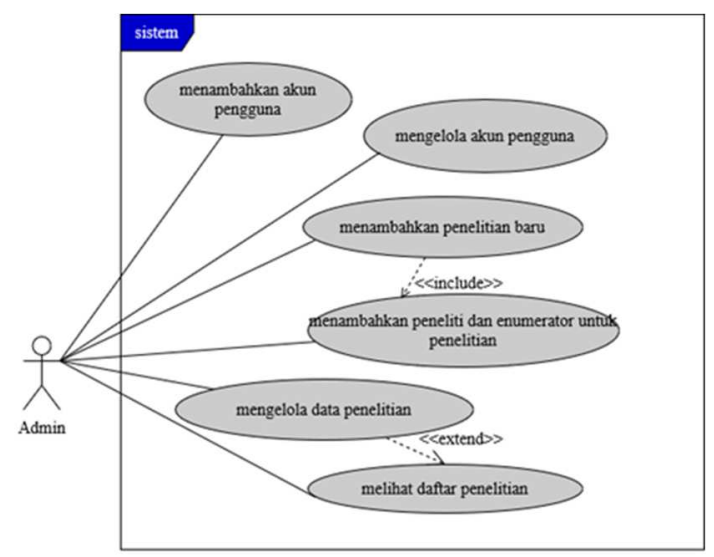

Gambar 8 Usecase Diagram Admin

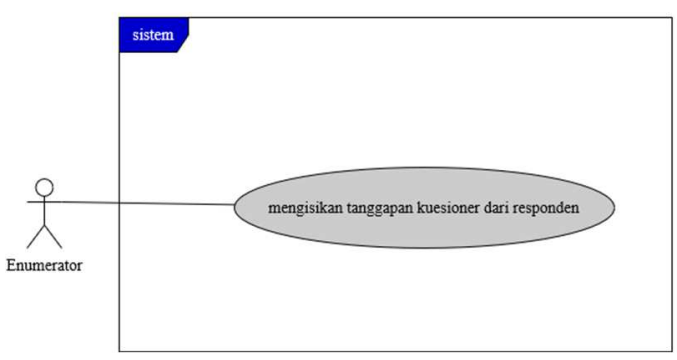

Gambar 9 Usecase Diagram Enumerator

Untuk Enumerator sesuai dengan Gambar 9 hanya dapat mengisikan tanggapan kuesioner dari responden. Hasil tanggapan ini nanti dapat diakses langsung oleh peneliti yang berguna untuk penelitian yang sedang dikerjakan.

Pimpinan seperti pada Gambar 10 dapat melihat data-data penelitian. Data ini termasuk data kuesioner dan data laporan penelitian.

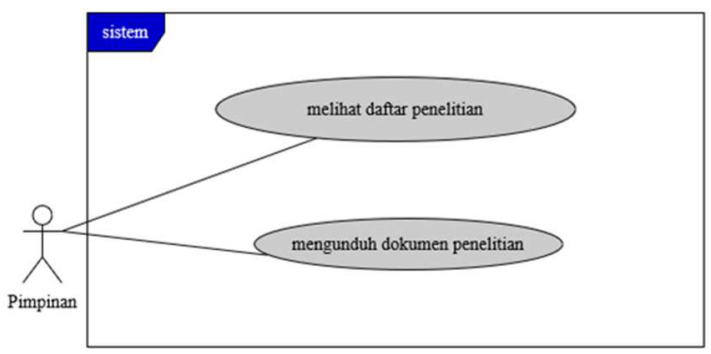

Gambar 10 Usecase Diagram Pimpinan

\section{Implementasi Dan Pengujian Sistem}

\section{Implementasi}

Pada program ini terbagi menjadi 2 modul yaitu pelatihan dan penelitian. Untuk pelatihan terbagi menjadi 4 user yaitu peserta, admin, widyaiswara dan pimpinan. Sedangkan pelatihan terbagi menjadi 4 user yaitu peneliti, admin, enumerator dan pimpinan.

1. Halaman Utama

Halaman utama merupakan halaman yang tampil pertama ketika user membuka website Sistem Informasi Pelatihan dan Penelitian. Sistem Informasi Pelatihan \& Penelitian Latbang Kalsel dapat diakses pada tautan http://www.latbangbkkbnkalsel.com/. Halaman Utama memiliki 2 button yaitu “Pelatihan" dan "Penelitian" dan 3 buah list yang untuk menuju halaman utama (home), Pelatihan dan Penelitian seperti pada Gambar 11.

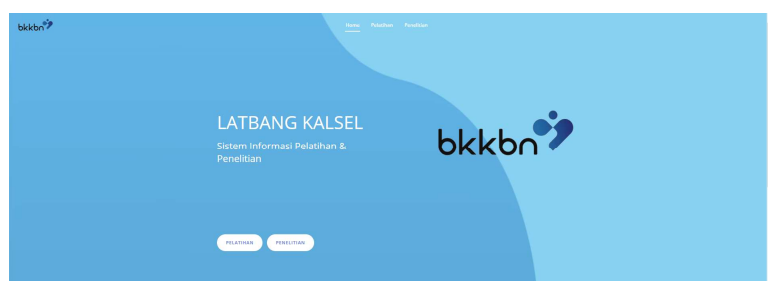

Gambar 11 Interface Halaman Utama

\section{Halaman Login Pelatihan}

Halaman login dapat diakses oleh semua user. Halaman ini memiliki 2 button yaitu button "Login" dan button "Buat akun". Selain button, halaman ini memiliki 2 buah textbox yang harus diisi yaitu username dan password seperti pada Gambar 12.

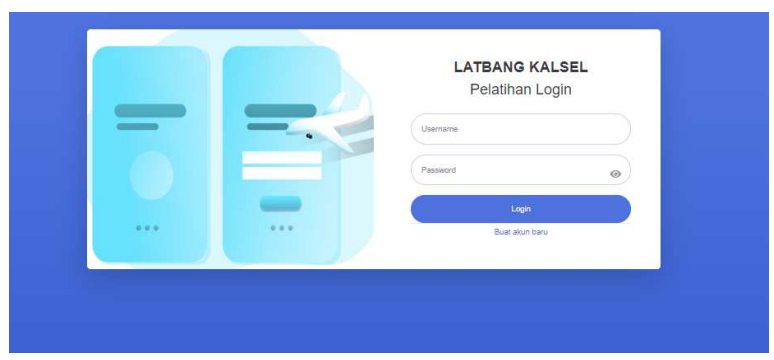

Gambar 12 Interface Halaman Login User

\section{Halaman Buat Akun Peserta Pelatihan}

Pada halaman ini terdapat halaman untuk pembuatan akun, yang pertama adalah halaman untuk memasukan kata kunci. Kata kunci akan diinformasikan oleh 
penyelanggara kepada peserta. Halaman untuk memasukan kata kunci terdiri dari 2 buah button yaitu button "Lanjut" dan button "Batal". Terdapat 1 buah textbox untuk memasukan kata kunci. Tampilan halaman masukan kata kunci seperti pada Gambar 13.

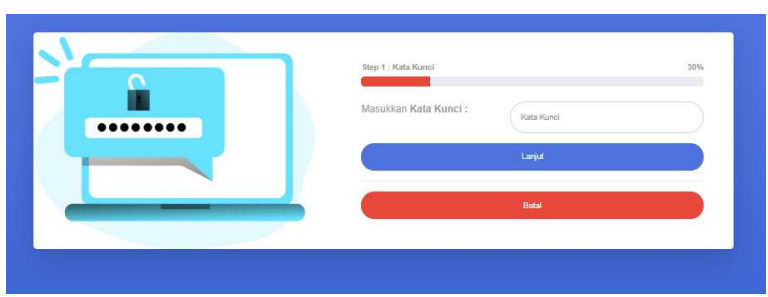

Gambar 13 Interface Halaman Masukan Kata Kunci

4. Halaman Login Penelitian

Halaman login memiliki 2 button yaitu button "login" dan button "buat akun". Selain button, halaman ini memiliki 2 buah textbox yang harus diisi yaitu username dan password seperti pada Gambar 14.

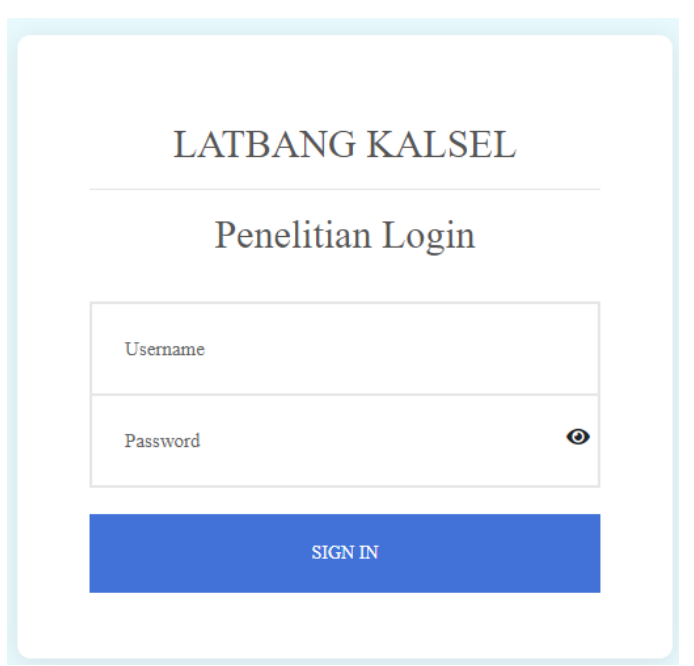

Gambar 14 Interface Halaman Login Penelitian

\section{Daftar Penelitian}

Pada Halaman daftar penelitian terdapat informasi tentang seluruh penelitian. Terdapat sidebar yang memuat menu pada modul penelitian. Selain sidebar, terdapat card yang memuat informasi tentang penelitian dan button "masuk" untuk melihat informasi tentang penelitian secara lebih rinci. Juga terdapat textbox untuk pencarian. Tampilan dapat dilihat seperti pada Gambar 15.
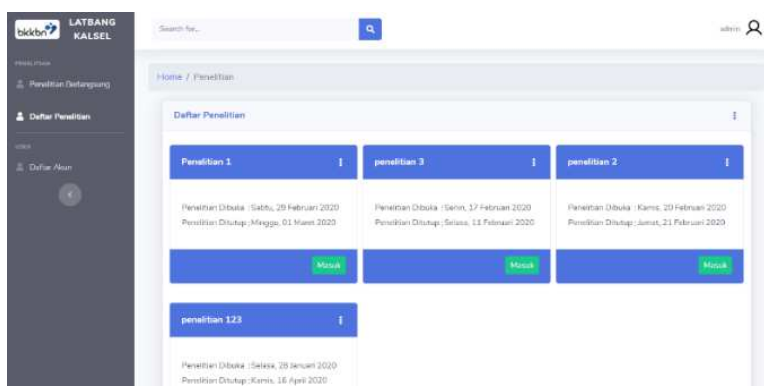

Gambar 15 Interface Halaman Daftar Penelitian

\section{Uji Coba Sistem dan Program}

Dalam uji coba sistem dan program menggunakan 2 sistem testing yaitu black-box dari sisi sistem dan usability dari sisi pengguna.

1. Black-box

Aplikasi ini tidak terdapat kesalahan sintaks dan kesalahan logika. Pada uji coba sistem digunakan blackbox testing. Pengujian black-box adalah metode pengujian perangkat lunak yang menguji fungsionalitas aplikasi yang bertentangan dengan struktur internal atau kerja(Kumar, Singh, \& Dwivedi, 2015; Syaikhuddin, Anam, Rinaldi, \& Conoras, 2018). Pengetahuan khusus dari kode aplikasi / struktur internal dan pengetahuan pemrograman pada umumnya tidak diperlukan. [38]. Hasil pengujian black-box untuk menguji fungsionalitas dengan menguji usecase pada kedua modul yaitu modul pelatihan dan penelitian dengan total 38 usecase dapat berjalan dengan semestinya. Adapun contoh hasil pengujian black-box pada pada Tabel 1.

\begin{tabular}{|c|c|c|c|c|}
\hline No & $\begin{array}{l}\text { Nama } \\
\text { Usecase }\end{array}$ & Aktor & Deskripsi & Sukses \\
\hline $\mathrm{UC1}$ & $\begin{array}{c}\text { Menamb } \\
\text { ahkan } \\
\text { Materi }\end{array}$ & $\begin{array}{l}\text { Widyai } \\
\text { swara }\end{array}$ & $\begin{array}{c}\text { Widyaiswara } \\
\text { dapat } \\
\text { menambahkan } \\
\text { dokumen materi } \\
\text { pelatihan }\end{array}$ & $\mathrm{Ya}$ \\
\hline $\mathrm{UC} 2$ & $\begin{array}{c}\text { Mengelol } \\
\text { a Materi } \\
\text { Pelatihan }\end{array}$ & $\begin{array}{l}\text { Widyai } \\
\text { swara }\end{array}$ & $\begin{array}{l}\text { Widyaiswara } \\
\text { dapat melakukan } \\
\text { pengubahan dan } \\
\text { penghapusan } \\
\text { terhadap materi } \\
\text { pelatihan }\end{array}$ & Ya \\
\hline
\end{tabular}

\section{Usability testing}

Definisi usability adalah sejauh mana suatu produk dapat digunakan oleh pengguna tertentu untuk mencapai target yang ditetapkan dengan efektivitas, efesiensi dan mencapai kepuasan penggunaan dalam konteks tertentu (Ritawati \& Fajar, 2019).

Langkah awal usability testing ini adalah memberikan sejumlah task atau tugas yang sudah dipersiapkan sebelumnya kepada pengguna saat berinteraksi dengan sistem yang diuji. Task-task ini diberikan kepada 73 orang responden yang berasal dari staff dan karyawan Deputi Latbang BKKBN Kalimantan Selatan yang sudah mengetahui sistem informasi pelatihan dan penelitian sehingga mereka tidak lagi mengalami kesulitan pada saat melakukan task-task tersebut. Task-task ini digunakan sebagai 'sarana interaksi' dalam pengukuran usability (Russ \& Saleem, 2018). Task-task untuk usability testing dapat dilihat seperti pada Tabel 2.

Setelah dilakukan penyebaran kuisioner yang diberikan pada 73 orang responden, maka selanjutnya dilakukan rekap terhadap hasil kuisioner yang telah disebar. Berdasarkan persentase hasil usability testing di atas, maka diperoleh Rekap Nilai Usability yang terlihat pada Tabel 3 
Tabel 2 Tabel task-task usability testing

\begin{tabular}{ll}
\hline No & \multicolumn{1}{c}{ Tugas } \\
\hline 1. & $\begin{array}{l}\text { Login kedalam sistem sebagai } \text { user } \\
\text { admin, kemudian logout dan lakukan } \\
\text { login kembali }\end{array}$ \\
2. & $\begin{array}{l}\text { Mencari Pelatihan atau Penelitian } \\
\text { dengan deskripsi kegiatan tersebut. }\end{array}$ \\
$3 . \quad \begin{array}{l}\text { Login sebagai Peserta pada modul } \\
\text { pelatihan dan mengisi form pendaftaran } \\
\text { sebuah pelatihan }\end{array}$ \\
L. & $\begin{array}{l}\text { Login sebagai enumerator pada modul } \\
\text { penelitian dan mengisi kuesioner }\end{array}$ \\
penelitian & $\begin{array}{l}\text { Menambah mengubah dan menghapus } \\
\text { data pelatihan dan penelitian pada } \\
\text { halaman admin }\end{array}$ \\
\hline
\end{tabular}

Tabel 3 Tabel rekap nilai usability testing

\begin{tabular}{|c|c|c|}
\hline No & Pertanyaan & Nilai \\
\hline \multicolumn{3}{|c|}{ Aspek Sistem } \\
\hline 1. & $\begin{array}{l}\text { Apakah tampilan Sistem Informasi } \\
\text { Pelatihan dan Penelitian mudah dikenali? }\end{array}$ & 4,069 \\
\hline 2. & $\begin{array}{l}\text { Apakah Sistem Informasi Pelatihan dan } \\
\text { Penelitian mudah dioperasikan? }\end{array}$ & 3,945 \\
\hline 3. & $\begin{array}{l}\text { Apakah tampilan warna pada Sistem } \\
\text { Informasi Pelatihan dan Penelitian enak } \\
\text { dilihat \& tidak membosankan? }\end{array}$ & 3,89 \\
\hline \multicolumn{3}{|c|}{ Aspek Pengguna } \\
\hline 4. & $\begin{array}{l}\text { Apakah tampilan menu dalam Sistem } \\
\text { Informasi Pelatihan dan Penelitian mudah } \\
\text { dikenali? }\end{array}$ & 3,904 \\
\hline 5. & $\begin{array}{l}\text { Apakah fitur dalam Sistem Informasi } \\
\text { Pelatihan dan Penelitian mudah dicari? }\end{array}$ & 3,945 \\
\hline 6. & $\begin{array}{l}\text { Apakah Sistem Informasi Pelatihan dan } \\
\text { Penelitian mudah dipahami? }\end{array}$ & 3,931 \\
\hline 7. & $\begin{array}{l}\text { Apakah halaman website Sistem Informasi } \\
\text { Pelatihan dan Penelitian mudah diakses? }\end{array}$ & 3,794 \\
\hline 8. & $\begin{array}{l}\text { Apakah simbol-simbol atau gambar pada } \\
\text { Sistem Informasi Pelatihan dan Penelitian } \\
\text { mudah dipahami? }\end{array}$ & 4,000 \\
\hline \multicolumn{3}{|c|}{ Aspek Interaksi } \\
\hline 9 & $\begin{array}{l}\text { Apakah menu dan tampilan halaman Sistem } \\
\text { Informasi Pelatihan dan Penelitian mudah } \\
\text { diingat? }\end{array}$ & 3,945 \\
\hline 10. & $\begin{array}{l}\text { Apakah informasi mengenai pelatihan } \\
\text { mudah didapatkan? }\end{array}$ & 3,904 \\
\hline 11 & $\begin{array}{l}\text { Apakah informasi mengenai penelitian } \\
\text { mudah didapatkan? }\end{array}$ & 3,644 \\
\hline 12 & $\begin{array}{l}\text { Apakah berkas/file yang dibutuhkan mudah } \\
\text { di download? }\end{array}$ & 3,89 \\
\hline \multicolumn{2}{|c|}{ Rata-Rata } & 3,905 \\
\hline
\end{tabular}

Tabel 3 menunjukkan nilai-nilai kepuasan atau penerimaan user (acceptance) terhadap masing-masing atribut. Dapat dilihat bahwa untuk atribut "Kemudahan interface sistem informasi pelatihan dan penelitian dikenali" memiliki nilai penerimaan usability oleh user sebesar 4,069 (sudah berada di atas 3 sebagai nilai tengah). Hal ini dapat diartikan bahwa sistem informasi pelatihan dan penelitian yang telah dibuat mudah dikenali oleh user dari halaman interface.

Apabila disesuaikan kembali hubungannya dengan masing-masing aspek usability dalam tabel 3, dapat dikatakan bahwa perangkat lunak sistem informasi pelatihan dan penelitian yang telah dibuat telah memiliki nilai Usability, yaitu: Learnability, Efficiency, Memorability, Errors, dan Satisfaction yang cukup baik. Hal ini ditunjukkan dengan nilai hasil usability pada kelima atribut, sebagai berikut:

a. Nilai atribut "Kemudahan interface sistem informasi pelatihan dan penelitian dikenali" sebesar 4,069 yang menunjukkan bahwa sistem informasi pelatihan dan penelitian telah memiliki nilai aspek Learnability.

b. Nilai atribut "Kemudahan sistem informasi pelatihan dan penelitian untuk dioperasikan" sebesar 3,945 menunjukkan bahwa sistem informasi pelatihan dan penelitian telah memiliki nilai aspek Efficiency.

c. Nilai atribut "Kemudahan mengingat kembali menu dan tampilan pada sistem informasi pelatihan dan penelitian" sebesar 3,945 menunjukkan bahwa sistem informasi pelatihan dan penelitian telah memiliki nilai aspek Memorability.

d. Nilai atribut "Kemudahan sistem informasi pelatihan dan penelitian yang ada mudah dipahami" sebesar 3,931; dan atribut "Simbol-simbol gambar mudah dipahami" sebesar 4,00 membuat sistem informasi pelatihan dan penelitian dapat dikatakan telah meminimalisasi aspek Errors.

e. Keseluruhan atribut yang memiliki nilai rata-rata 3,905, menunjukkan jika sistem informasi pelatihan dan penelitian telah mempunyai aspek Satisfaction yang cukup baik.

\section{Kesimpulan}

Sistem informasi pelatihan dan penelitian telah diimplementasikan untuk menyediakan informasi kepada deputi Latbang BKKBN. Fakta-fakta akan membantu dan meningkatkan keseluruhan proses pengambilan keputusan untuk menghasilkan keputusan strategis yang akurat dan tepat waktu. Sistem informasi pelatihan dan penelitian dapat digunakan dengan baik oleh instansi dalam manajemen data dan menghemat biaya operasional, hal ini dibuktikan dengan penilaian usability testing oleh pegawai BKKBN Provinsi Kalimantan Selatan dengan rata-rata nilai 3,905, nilai ini melebihi 3 (cukup mudah) sebagai nilai tengah dari skala 1 (sangat sulit) sampai dengan 5 (sangat mudah). Serta dari uji coba sistem menggunakan metode black box testing dengan hasil $100 \%$ berhasil untuk semua modul pada sistem. 


\section{Ucapan Terimakasih}

Terimakasih kepada Rektor ULM, Dekan Fakultas Teknik ULM, Koordinator Program Studi Profesi Insinyur dan kepada teman - teman penting yang mendukung selesainya program insinyur. Terimakasih juga pada Rafi, Aziza, Radiya dan lqbal yang telah membantu dalam proyek penulis.

\section{Referensi}

Arvidsson, V., Holmström, J., \& Lyytinen, K. (2014). Information systems use as strategy practice: A multidimensional view of strategic information system implementation and use. Journal of Strategic Information Systems, 23(1), 45-61. https://doi.org/10.1016/j.jsis.2014.01.004

Dennis, A., Wixom, B. H., \& Roth, R. M. (2012). System Analysis \& Design. In John Wiley \& Sons, Inc. (5th ed.). Amerika Serikat.

Evans, A., France, R., Lano, K., \& Rumpe, B. (1998). Developing the UML as a Formal Modelling Notation.

Galliers, R. D., Jarvenpaa, S. L., Chan, Y. E., \& Lyytinen, K. (2012). Strategic information systems: Reflections and prospectives. Journal of Strategic Information Systems, 21(2), 85-90. https://doi.org/10.1016/j.jsis.2012.07.001

Kedeputi Bidang Pelatihan, P. dan P. (2020). Laporan Kinerja Instansi Pemerintah. Badan Kependudukan Dan Keluarga Berencana Nasional Jakarta. https://doi.org/10.1017/СB09781107415324.004

Kornberger, M., \& Clegg, S. (2011). Strategy as performative practice: The case of Sydney 2030. Strategic Organization, 9(2), 136-162. https://doi.org/10.1177/1476127011407758
Kumar, M., Singh, S. K., \& Dwivedi. (2015). A Comparative Study of Black Box Testing and White Box Testing Techniques. International Journal of Advance Research in Computer Science and Management Studies, 3(10), 32-44. Retrieved from http://www.ijarcsms.com/docs/paper/volume3/issu e10/V3I10-0018.pdf

Merali, Y., Papadopoulos, T., \& Nadkarni, T. (2012). Information systems strategy: Past, present, future? Journal of Strategic Information Systems, 21(2), 125153. https://doi.org/10.1016/j.jsis.2012.04.002

Padmanabhan, B. (2012). Unified Modeling Language (UML) Overview. EECS810 - Principles of Software Engineering.

Presiden Republik Indonesia. (2010). Peraturan Presiden Republik Indonesia Nomor 62 Tahun 2010 Tentang Badan Kependudukan Dan Keluarga Berencana Nasional.

Ritawati, \& Fajar, A. N. (2019). Analysis usability and content in known system implementation. Journal of Theoretical and Applied Information Technology, 97(6), 1788-1796.

Russ, A. L., \& Saleem, J. J. (2018). Ten factors to consider when developing usability scenarios and tasks for health information technology. Journal of Biomedical Informatics, 78(January), 123-133. https://doi.org/10.1016/j.jbi.2018.01.001

Syaikhuddin, M. M., Anam, C., Rinaldi, A. R., \& Conoras, M. E. B. (2018). Conventional Software Testing Using White Box Method. Kinetik, 3(1), 67. https://doi.org/10.22219/kinetik.v3i1.231

Thomas, B., \& Johnson, J. (2012). Cocreating IT value: New capabilities and metrics for multifirm environments. MIS Quarterly, 36(1), 225-232. 